\begin{tabular}{c} 
International Journal of Advanced Chemistry, 2(2)(2014) 171-174 \\
International Journal of Advanced Chemistry \\
Journal home page: $\begin{array}{c}\text { www.sciencepubco.com/index.php/IJAC } \\
\text { doi: } 10.14419 / \text { ijac.v2i2.3496 } \\
\text { Research Paper }\end{array}$ \\
\hline
\end{tabular}

\title{
Proximate composition, mineral and phytochemical constituents of Eleusine coracana (finger millet)
}

\author{
Bwai Macham David *, Afolayan Michael, Odukomaiya Doyinsola, Ikokoh Patrick, Orishadipe Abayomi \\ Chemistry Advanced Laboratory, Sheda Science and Technology Complex (SHESTCO), P.M.B.186, Garki - Abuja, Nigeria \\ *Corresponding author E-mail: machamdavidb@yahoo.com
}

\begin{abstract}
The proximate composition, mineral and phytochemical constituents of Eleusine coracana (finger millets) was evaluated with the aim of providing data that will guide the effective utilization of it under exploited seed in food application. The proximate composition revealed the presence of moisture $(6.99 \%)$, ash $(2.37 \%)$, crude protein $(10.28 \%)$, crude fibre $(3.10 \%)$, crude lipid $(0.83 \%)$ and carbohydrate (76.43\%). The mineral composition revealed potassium $(14.19 \mathrm{mg} / \mathrm{g})$, sodium $(6.86 \mathrm{mg} / \mathrm{g})$, copper $(0.10 \mathrm{mg} / \mathrm{g}), \mathrm{calcium}(1.13 \mathrm{mg} / \mathrm{g})$, magnesium $(6.25 \mathrm{mg} / \mathrm{g})$, zinc $(0.22 \mathrm{mg} / \mathrm{g})$, manganese $(0.32 \mathrm{mg} / \mathrm{g})$, Iron $(0.11 \mathrm{mg} / \mathrm{g})$, lead $(0.001 \mathrm{mg} / \mathrm{g})$ and Na/K 0.48 . The phytochemical constituents present were tannins, steroids, phenols, alkaloids, terpenoids, cardiac glycosides and balsams. These results revealed that the seeds of Eleusine coracana (finger millet) contained essential nutrients which compete favourably well with those of other seeds in literature and it is suitable for health benefits and for use in herbal medicine to combat different diseases.
\end{abstract}

Keywords: Eleusine Coracana, Finger Millet, Mineral Composition, Phytochemical, Proximate, Seed.

\section{Introduction}

Good nutrition is a basic human right. In order to have a healthy population that can promote development, the relation between food, nutrition and health should be reinforced. In developing countries, one of the ways of achieving this is through the exploitation of available local resources, in order to satisfy the needs of the increasing population (Achu et al. 2005). Knowledge of nutrition value of local dishes, soup ingredients and local foodstuffs is necessary in order to encourage the increase cultivation and consumption of this highly nutritive seed. The consumption will help to supplement the nutrients of the staple protein foods (Achu et al. 2005).

In recent years, there has been gradual revival of interest in the use of medicinal plants in developing countries because herbal medicines have been reported safe and without any adverse side effect especially when compared with synthetic drugs. Thus a search for new drugs with better and medicinal substituent from plant origin is a natural choice. The medicinal value of these plants lies in some chemical substances that produce a definite physiological action on the human body (Edeoja et al. 2005).

Finger millet is a fast growing cereal crop that reaches maturity within 3-6 months and sometimes in only 45 days (Dida et al. 2006). It is generally found in disturbed areas, roadsides and banks (Quattrocchi, 2006). It is commonly found between 1000 and $2000 \mathrm{~m}$ altitude in eastern and southern Africa and up to 2500$3000 \mathrm{~m}$ altitude in the Himalayas (FAO, 2012; Dida et al., 2006). It grows best at about $23^{\circ} \mathrm{C}$ average temperature but can withstand some cooler and hotter conditions (FAO, 2012). Annual rainfall ranging from $500-1000 \mathrm{~mm}$, are suitable, provided it is well distributed during the growing season (Dida et al. 2006). Finger millet will keep growing in drier conditions pearl millet and sorghum will be preferred below $750 \mathrm{~mm}$ (de Wet, 2006). Finger millet is intolerant of flooded conditions but withstands some waterlogging. It does not do well in areas of heavy rains, but prefers damp conditions (Baker, 2003). Finger millet is adapted to a wide range of soil conditions though it prefers fertile, well-drained sandy to sandy loamy soils with $\mathrm{pH}$ ranging from 5 to 7 . It still grows on lateritic or black heavy vertisols and has some tolerance for alkaline and moderately saline soils (Dida et al. 2006).

Finger millet is a staple food in many African and South Asian countries. It is also considered a helpful famine crop as it is easily stored for lean years (FAO, 2012). The grain is readily digestible, highly nutritious and versatile: it can be cooked like rice, ground to make porridge or flour or used to make cakes (de Wet, 2006). Sprouted grains are recommended for infants and elderly people. Finger millet is also used to make liquor ("arake" or "areki" in Ethiopia) and beer, which yields by-products used for livestock feeding (FAO, 2012). In Daffo Bokkos L.G.A of Plateau State of Nigeria finger millet is used in making local drinks "kunu" no wonder people living in these areas are so fit and healthy.

The purpose of this study is aimed at evaluating the nutritional value and phytochemical properties of the seed grown in Nigeria. This will aid promotion of the use of the seeds in the management of the nutrition-related problems in Nigeria in particular and in Africa in general.

\section{Materials and methods}

Finger millet seeds were obtained from Daffo, Bokkos LGA of Plateau State Nigeria and were identified at Federal college of forestry, Jos, Plateau state as Eleusine coracana. The seed samples were grinded into powder using mortar and pestle and then stored in air-tight container for all the chemical analysis.

\subsection{Chemicals and reagents}


All the chemicals and reagents used in this study were of analytical grade and were products of British Drug House Laboratory, England.

\subsection{Sample analysis}

The proximate analyses were carried out in triplicates and the results obtained were the average values. The estimation of the various food parameters in Eleusine coracana seed was carried out using the methods of AOAC (1990).

Mineral analysis was carried out after $2 \mathrm{~g}$ of the seed sample was ashed and $10 \mathrm{ml}$ of Conc. $\mathrm{HNO}_{3}$ was added to it and digested until a clear solution was obtained. The digest was allowed to cool and then transferred into a $100 \mathrm{ml}$ standard flask and made up to mark with de-ionized water. The mineral elements were analyzed with atomic absorption spectrophotometer (GBC Avanta Ver 2.02 Model, Australia) equipped with air-acetylene flame. Sodium and potassium were determined using a flame photometer (Gallenkamp flame analyser, UK).

\subsection{Hexane, ethyl acetate and ethanol extraction of seeds}

The hexane, ethyl acetate and ethanol extract were extracted from the resulting powder by adopting the method described by A.O.A.C (AOAC, 1980), which entailed using soxhlet apparatus to extract with hexane, ethyl acetate and then ethanol. $200 \mathrm{~g}$ of the ground seed-kernel were packed in muslin cloth and inserted into the soxhlet extractor and hexane was used as the extracting solvent for a period of eight hours. At the end of this period, the solvent was recovered by rotary evaporator and residual extract was ovendried at $75^{\circ} \mathrm{C}$ for one hour. Ethyl acetate was also used as extracting solvent for another period of eight hours. At the end of this period, the solvent was recovered by rotary evaporator and the residual extract dried at $85^{\circ} \mathrm{C}$ for one hour. Same applicable for ethanol. The three extracts were then transferred to a desicator and allowed to cool before being kept for analytical tests.

\subsection{Phytochemical screening}

Chemical tests were carried out on the hexane, ethyl acetate and ethanolic extracts for the qualitative determination of phytochemical constituents as describe by Harborne (1973), Trease and Evans (1989) and Sofowora (1993).

\section{Results and discussion}

The chemical, mineral and phytochemical analysis results are presented in Tables $1-3$ below.

Table 1 presents proximate composition of the finger millet. The moisture content of the Eleusine coracana is $6.99 \pm 0.02 \%(\mathrm{w} / \mathrm{w})$. This indicates that the seed has a good shelf life; hence it can be stored for long term without spoilage. Moisture content is among the most vital and mostly used measurement in the processing, preservation and storage of food (Onwuka, 2005). Ash content of $2.37 \pm 0.01 \%(\mathrm{w} / \mathrm{w})$ was obtained as a result for Eleusine coracana. Ash in food contributes the residue remaining after all the moisture has been removed as well as organic material have been incinerated at a temperature of about $550^{\circ} \mathrm{C}$. Ash content is generally taken to be a measure of the mineral content of the original food (Onwuka, 2005).

Crude fibre in food is an indication of the level of non-digestible carbohydrate and lignin. The value of $3.10 \pm 0.03$ in Eleusine coracana is considered appropriate, because it aids absorption of glucose, poison, fat and also increase fecal sample. Although crude fibre enhances digestibility, its presence in high level can cause intestinal irritation, lower digestibility and decreased nutrient usage (Oladiji et al, 2005). The crude lipid content obtained for Eleusine coracana was $0.83 \pm 0.01 \%(\mathrm{w} / \mathrm{w})$. Lipid provides very good sources of energy and aids in transport of fat soluble vitamins, insulates and protects internal tissues and contributes to important cell processes (Jones et al., 1985, Pamela et al., 2005). More so, it is good to add lipid (fat) to most of our diets, because many body functions depend on lipids.

The crude protein of Eleusine coracana is $10.28 \pm 0.01 \%$ (w/w). The recommended dietary allowance (RDA) for protein is $56 \mathrm{~g}$ for individual weighing $70 \mathrm{~kg}$ and $46 \mathrm{~g}$ for adult weighing $50 \mathrm{~kg}$, children may consume $2 \mathrm{~kg} / \mathrm{day}$ (Jones et al., 2005). The plant is a moderate source of protein. According to Pamela et al., (2005), proteins from plant sources have lower quality but their combination with many other sources of protein such as animal protein may result in adequate nutritional value. The carbohydrate content of Eleusine coracana was $76.43 \pm 0.02 \%$. The plant is a good source of carbohydrate when compared with the Recommended Dietary Allowance (RDA) of 130g (Pamela et al., 2005). The caloric value of Eleusine coracana was $382.27 \pm 0.02 \mathrm{kcal} / \mathrm{g}$. An average person requires $2000-3000 \mathrm{kcal}$ per day (Jones et al., 1985). The plant can contribute to the caloric requirement of the body.

Table 1: Chemical Composition of Eleusine Coracana (Finger Millet)

\begin{tabular}{ll}
\hline Component & Value \\
\hline Moisture & $6.99 \pm 0.02 \%$ \\
Crude fibre & $3.10 \pm 0.03 \%$ \\
Crude fat & $0.83 \pm 0.01 \%$ \\
Ash & $2.37 \pm 0.01 \%$ \\
Crude Protein & $10.28 \pm 0.02 \%$ \\
Carbohydrates & $76.43 \pm 0.02 \%$ \\
Caloric Value & $382.27 \pm 0.02 \mathrm{Kcal} / \mathrm{g}$ \\
\hline
\end{tabular}

Table 2: Mineral Composition of Eleusine Coracana (Finger Millet)

\begin{tabular}{ll}
\hline Minerals & Concentration $(\mathrm{mg} / \mathrm{g})$ \\
\hline Sodium & $6.86 \pm 0.02$ \\
Potassium & $14.19 \pm 0.03$ \\
Calcium & $1.13 \pm 0.01$ \\
Iron & $0.11 \pm 0.01$ \\
Manganese & $0.32 \pm 0.02$ \\
Copper & $0.10 \pm 0.01$ \\
Magnesium & $6.25 \pm 0.02$ \\
Zinc & $0.22 \pm 0.01$ \\
Cobalt & Nil \\
Lead & $0.001 \pm 0.0001$ \\
Cadmium & Nil \\
Chromium & Nil \\
Na/K & $0.48 \pm 0.02$ \\
\hline
\end{tabular}

Table 3: Phytochemical Analysis Result of Eleusine Coracana (Finger Millet)

\begin{tabular}{llll}
\hline Compound & $\begin{array}{l}\text { Hexane ex- } \\
\text { tract }\end{array}$ & $\begin{array}{l}\text { Ethylacetate ex- } \\
\text { tract }\end{array}$ & $\begin{array}{l}\text { Ethanol ex- } \\
\text { tract }\end{array}$ \\
\hline Tannins & - & - & + \\
Steriod & - & + & + \\
Triterperoid & - & - & - \\
Glycoside & - & - & - \\
Saponin & - & - & - \\
Phenol & - & - & + \\
Alkaloids & + & + & - \\
Terpenoids & + & + & + \\
Carbohydrates & - & - & + \\
Flavanoid & - & - & - \\
Cardiac glyco- & + & + & + \\
side & + & - & - \\
Phlobatannins & - & - & - \\
Resins & - & - & + \\
Balsams & - & - & - \\
Volatile oil & - & & \\
\hline
\end{tabular}

Table 2 presents the result of mineral element composition of Eleusine coracana, in $\mathrm{mg} / \mathrm{kg}$ dry matter. The zinc content of Eleusine coracana was $0.22 \pm 0.01 \mathrm{mg} / \mathrm{g}$. The Recommended Dietary Allowance (RDA) for zinc is $13 \mathrm{mg} / \mathrm{kg}$ (Jone et al., 1985). Zinc is essential in the activation of certain enzymes. These include dehydrogenase, alkaline phosphatese and carboxypeptidase. Zinc containing organic compounds is employed as astringent and antifungal agents. It aids wound healing and metabolism of nucleic acid and insulin. Zinc in excess causes anaemia and if deficient 
in the body can lead to dermatitis. The value obtained for lead $(\mathrm{Pb})$ was $0.001 \pm 0.0001 \mathrm{mg} / \mathrm{g}$. Effect of lead deficiency in the body results in anemia while excess lead $(\mathrm{Pb})$ in the body can cause brain damage (Stoker, 1976).

The manganese content of Eleusine coracana was $0.32 \pm 0.02 \mathrm{mg} / \mathrm{g}$. The Recommended Dietary Allowance (RDA) for manganese varies between $2 \mathrm{mg} / \mathrm{kg}$ to $8 \mathrm{mg} / \mathrm{kg}$ (Jones et al., 1985). Certain trace elements such as copper, iron, and manganese constitute essential part of any balanced diet. Some of them are micronutrient to the plants and if not present in the right proportion may have adverse effect on human and plants. The content of copper was $0.68 \pm 0.11 \mathrm{mg} / \mathrm{kg}$. The Recommended Dietary Allowance of copper according to Jones et al., (1985) is $3.5 \mathrm{mg}$. Copper is very vital in diet because it is involved in the proper usage of iron $(\mathrm{Fe})$ and especially for the synthesis of cytochrome oxidase, which contains both iron $(\mathrm{Fe})$ and copper $(\mathrm{Cu})$. Excess copper can lead to jaundice (Wilson's disease) (Stoker, 1974).

The potassium content was $14.19 \pm 0.03 \mathrm{mg} / \mathrm{g}$. According to National Research Council (1974), the Recommended Dietary Allowance of potassium is $1875-5625 \mathrm{mg} / \mathrm{kg}$ for adults. Potassium is very vital in regulation of water and electrolyte balance and acidbase balance in the body, as well as responsible for nerve action and functioning of the muscles. Deficiency of potassium leads to muscle paralysis (Michael, 2007). The sodium content was $6.86 \pm 0.02 \mathrm{mg} / \mathrm{g}$. Sodium is a very important mineral element that aids the transmission of nerve impulses as well as maintenance of osmotic balance of the cells. According to National Research Council (1974), the Recommended Daily Allowance for sodium is $1100-3300 \mathrm{mg} / 100 \mathrm{~g}$ for adults. Deficiency of sodium may lead to dehydration or muscle cramp (Michael, 2007).

The iron content of Eleusine coracana was $0.11 \pm 0.01 \mathrm{mg} / \mathrm{g}$. According to Bolt et al., (1978), the recommended daily requirement of iron for man is $6-40 \mathrm{mg} / \mathrm{kg}$. Iron is very important in the formation of haemoglobin in red blood cells and deficiency of iron leads to anaemia. Eleusine coracana could be used to improve the anaemic condition of a patient.

The value obtained for calcium was $1.13 \pm 0.01 \mathrm{mg} / \mathrm{g}$. The Recommended Dietary Allowance for calcium is $600-1400 \mathrm{mg}$ (Bolt et al., 1978). Calcium is essential for bone and teeth formation and development, blood clotting and for normal functioning of heart, nervous system and muscles. Calcium deficiency can lead to ricket, osteomalacia and tooth decay (Michael, 2007). Excess calcium may in the soil interfere with phosphorus and boron nutrient and may encourage chlorosis because of reduction of soil manganese, iron and zinc (Brady, 1974).

The results of the phytochemical composition (Table 3), indicates that the seed E. coracana is rich in phytochemical such as alkaloid (hexane and ethyl acetate fraction), phenol (ethanol extract), tannins (ethanol extract), steroids (ethyl acetate and ethanol extract), terpenoids (all extract), carbohydrates (ethanol extract), cardiac glycosides (all extract) and balsams (ethanol extract). The presence of these secondary metabolites will contribute to its medicinal value as well as physiological activity (Sofowora, 1993). For instance, alkaloid contributes to plant species fitness of survival. They often have pharmacological effects and are used as medication and recreational drugs (Rodgers and Wink, 1998). Steroidal compounds are of importance in pharmacy because of their relationship with compounds used as sex hormones (Okwu, 2001) Plant terpenoids are used for their aromatic qualities. They play a role in traditional herbs and are under investigation for antibacterial, antineoplastic, and other pharmaceutical functions (Michael, 2009). Tannins which is present in ethanol extract affect in vitro protein digestibility but it is unclear whether they are detrimental to animal nutrition (Ramachandra et al., 1977). Phenolic compounds which are present in ethanolic extract are reported to exert a wide spectrum of biological effects such as- antioxidant and free radical scavenging activity and antimicrobial activity (Volluri et al., 2011 and Cowan, 1999) while cardiac and anthraquinone glycosides are reported to have antibacterial and antifungal activity (Ebana et al., 1991 and Wothi-Udomlert et al., 2010).

\section{Conclusion}

The present results show that Eleusine coracana is a rich source of primary metabolites and has the potentiality of use as a nonconventional food to supplement the nutritional needs of the under-nourished population. Due to the ignorance of the cultivated plants as food products, there is a high demand of commercial seed, the production of which is seldom enough to meet the nutritional requirement of the population. Hence, it becomes essential and urgent to create community awareness so that the people may go into cultivation of the seed plant. Moreover, the presence of different types of secondary metabolites in the studied plant makes it suitable for health benefits and for use in herbal medicine to combat different diseases.

\section{References}

[1] Edeoja HO, Okwu DE and Mbaebie BO (2005). Phytochemical constituents of some Nigerian medicinal plants. African Journal Biotechnology. 4:685-688. http://dx.doi.org/10.5897/AJB2005.000-3127.

[2] Achu MB, Fokou E, Tchiegang C, Fotso $M$ and Tchouanguep FM (2005). Nutritive value of some cucurbitaceae oil seeds from different regions in Cameroon. African Journal Biotechnology, 4:1329-1334.

[3] De Wet, JM J (2006). Eleusine coracana (L.) Gaertn. Record from Protabase. Brink, M. \& Belay, G. (Editors). PROTA (Plant Resources of Tropical Africa / Ressources végétales de l'Afrique tropicale), Wageningen, Netherlands.

[4] FAO (2012). Grassland Index. A searchable catalogue of grass and forage legumes. FAO, Rome, Italy.

[5] Dida MM and Devos KM (2006). Finger millet. In: Chittarajan, K., Genome Mapping and Molecular Breeding in Plants, Springer-Verlag, 1: 333-344.

[6] Quattrocchi U (2006). CRC World dictionary of grasses: common names, scientific names, eponyms, synonyms, and etymology. CRC Press, Taylor and Francis Group, Boca Raton, USA pg 23-35

[7] Baker RD (2003). Millet production. Guide A-414, New Mexico State University, $8 \mathrm{p}$

[8] Harborne JB (1973). Phytochemical methods. Chapman and Hall Ltd. London. Pp: 49-188.

[9] Soforowora LA (1993). Medicinal plants and traditional medicine in Africa. Spectrum Books Ltd, Ibadan. Harbone.pp. 55-71.

[10]Trease GE and Evans WC (1989). Trease and Evans' pharmacognosy: A physician's Guide to Herbal Medicine. $13^{\text {th }}$ Edition, Bailliere Tindall London.pp 56-58.

[11]AOAC (1980) Official Method of Analysis $13^{\text {th }}$ edition. William Horwitz edition Washington DC. Association of Official Analytical Chemist 7:56-132.

[12]AOAC (1990). Official methods of analysis. $15^{\text {th }}$ Edn., Association of Official Analytical Chemists, Washington DC.

[13] Sofowora EA (1993). Medical plants and traditional medicine in Africa spectrum Books Ltd, Ibadan. Pp 55-71.

[14]Rodger MF and Wink M (1998). Alkaloids Biochemistry, ecology and medical applications. Plennum press pp2-3.

[15] Okwu DE (2001). Evaluation of the chemical composition of indigenous species and flavouring agents. Global J. Pure Applied Sci. 7:455469.

[16]Michael S (2009). A life of its own. The New Yorker. Pp 25-28.

[17]Ramachandra G, Virupaksha T K, Shadaksharaswamy M (1977). Relation between tannin levels and in vitro protein digestibility in finger millet (Eleusine coracana Gaertn.). J. Agric. Food Chem., 25 (5): 1101-1104 http://dx.doi.org/10.1021/jf60213a046.

[18] Onwuka G I (2005). Food Analysis and Instrumentation; Theory and Practice. Naphthalic prints, Surulere, Lagos, Nigeria. 219- 230.

[19]Oladiji AT and Mih FO (2005). African J. Biotech., 4 (12): 14401441.

[20]Volluri SS, Bammidi SR, Chippada SC, Vangalapati M (2011). Rasayan J Chem, 4(2), 381-386.

[21]Cowan MM (1999). Clinical Microbiology Reviews, 12(4), 564-582.

[22]Ebana RUB, Madunagu BE, Ekpe ED and Otung IN (1991). Journal of Applied Bacteriology, 71,398-401. http://dx.doi.org/10.1111/j.1365-2672.1991.tb03807.x.

[23]Wuthi-udomlert M, Kupittayanant P, Gritsanapan W (2010).Journal of Health Research, 24,117-122.

[24]Jones MM, Johnson DO, Netlerville JT, Wood JI and Joesten MD (1985). Chemistry and Society. 5th ed., Saunders College Publishers U. S. A., 521- 577 . 
[25]Pamela CC, Richard AH and Denise RF (2005). Lippincotts illustrated Reviews Biochemistry 3rd ed., Lippincott Williams and Wilkins, Philadelphia, pp. 335- 388.

[26]Stoker SH (1976). Environmental Chemistry: air and water pollution. 2nd ed., Wiley Interscience Publishers, U.S.A. 2- 29.

[27]National Research Council (1974). Recommended daily dietary allowance, USA Nutrition Review. 31 (12): 374 - 390.

[28]Bolt GH and Bruggenwert WG (1978). Solid Chemistry, basic elements. Elsevier Scientific Publishing Co., New York. 145.

[29]Michael WK (2007). Medical Biochemistry. 3rd ed., Queen Mary Publishers London, pp. 13 - 17.

[30]Brady NC (1974). The Nature and Properties of Soil. 8th ed., Macmillan Publishers C. O. Inc. New York. 40-45. 